\section{orn}

OAK

RIDGE

NATIONAL

LABORATORY

\section{UNION}

CARBIDE

\title{
Mission Statement for the \\ Engineering Test Facility \\ MASTER
}

\section{ETF Design Center Team}

OPERATED BY

UNION CARBIDE CORPORATION FOR THE UNITED STATES DEPARTMENT OF ENERGY
DSTRIBUTION of ThS DOEUMENT is UHUMITEO

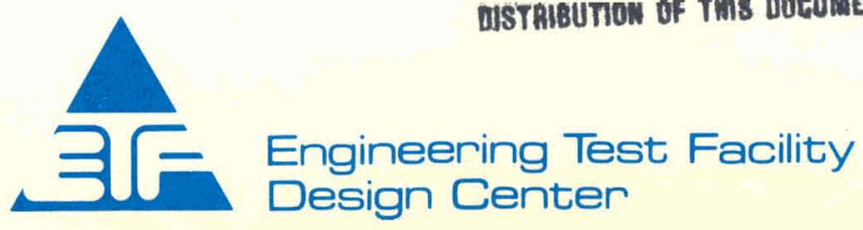




\section{DISCLAIMER}

This report was prepared as an account of work sponsored by an agency of the United States Government. Neither the United States Government nor any agency Thereof, nor any of their employees, makes any warranty, express or implied, or assumes any legal liability or responsibility for the accuracy, completeness, or usefulness of any information, apparatus, product, or process disclosed, or represents that its use would not infringe privately owned rights. Reference herein to any specific commercial product, process, or service by trade name, trademark, manufacturer, or otherwise does not necessarily constitute or imply its endorsement, recommendation, or favoring by the United States Government or any agency thereof. The views and opinions of authors expressed herein do not necessarily state or reflect those of the United States Government or any agency thereof. 


\section{DISCLAIMER}

Portions of this document may be illegible in electronic image products. Images are produced from the best available original document. 
Printed in the United States of America. Available from National Technical Information Servire.

U.S. Department of Commerce

5285 Port Royal Road, Springfield, Virginia 22161

NTIS price codes-Printed Copy: A03; Microfiche A01

This report was prepared as an account of work sponsored by an agency of the United States Government. Neither the United States nor any agency thereof, nor any of their employees, makes any warranty, expressed or implied, or assumes any legal liability or responsibility for any third party's use or the results of such use of any information, apparatus, product or process disclosed in this report, or represents that its use by such third party would not infringe privately owned rights. 
Contract No. W-7405-eng-26

MISSION STATEMENT FOR THE ENGINEERING TEST FACILITY

ETF Design Center Team

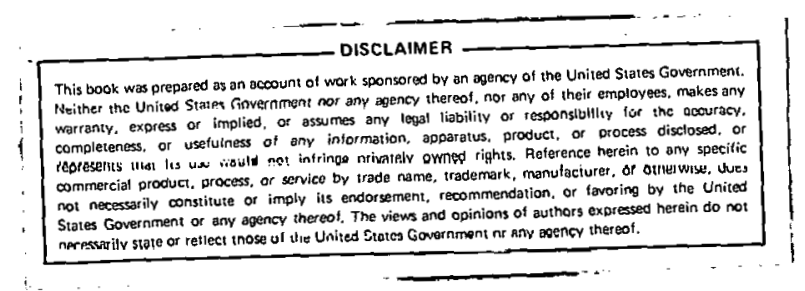

Prepared by the

OAK RIDGE NATIONAL LABORATORY

Oak Ridge, Tennessee 37830

operated by

UNION CARBIDE CORPORATION

for the

DEPARTMENT OF ENERGY 
THIS PAGE

WAS INTENTIONALLY

LEFT BLANK 
ABSTRACT $\ldots \ldots \ldots \ldots \ldots \ldots \ldots \ldots \ldots \ldots \ldots \ldots \ldots \ldots \ldots \ldots \ldots \ldots \ldots \ldots \ldots \ldots \ldots$

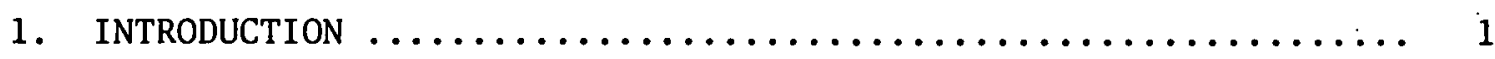

2. DEFINITION OF THE MISSION STATEMENT $\ldots \ldots \ldots \ldots \ldots \ldots \ldots \ldots \ldots \ldots$

3. ANTICIPATED FUSION KNOWLEDGE PRIOR TO ETF OPERATION ........ 4

4. ACHIEVEMENTS/MILESTONES $\ldots \ldots \ldots \ldots \ldots \ldots \ldots \ldots \ldots \ldots \ldots \ldots \ldots$

5. TESTING SCHEDULE REQUIREMENTS $\ldots \ldots \ldots \ldots \ldots \ldots \ldots \ldots \ldots \ldots \ldots \ldots$

6. FACILITY DESCRIPTION AND DESIGN REQUIREMENTS $\ldots \ldots \ldots \ldots \ldots \ldots \ldots 12$

APPENDIX: ANTICIPATED FUSION KNOWLEDGE IN $1990 \ldots \ldots \ldots \ldots \ldots \ldots \ldots$ 
THIS PAGE

WAS INTENTIONALLY

LEFT BLANK 


\begin{abstract}
This Mission Statement defines the ETF activity during its operating life. The results of those operations must provide the data, knowledge, experience, and confidence to continue to the next steps beyond ETF in making fusion power a viable energy option. The results from the ETF mission (operations are assumed to start early in the $1990^{\prime} \mathrm{s}$ ) are to bridge the gap between the base of magnetic fusion knowledge at the start of operations and that required to design the EPR/DEMO devices.
\end{abstract}




\section{INTRODUCTION}

In September 1978 John Deutch, Director of Energy Research for the U.S. Department of Energy (DOE), articulated the DOE policy for fusion energy. This policy statement encompassed the efforts in both the magnetic confinement and the inertial confinement approaches. In order to develop fusion energy as an economically attractive and environmentally acceptable energy option, the DOE policy statement on fusion energy outlined a three-phase strategy. Sequentially these phases focus on scientific feasibility, engineering testing, and reactor demonstration.

It is anticipated that scientific feasibility will be achieved within the $1980^{\prime}$ 's for both the magnetic confinement approach and the inertial confinement approach. Following the achievement of scientific feasibility, each of the two approaches would move from the applied research phase into an engineering testing phase. The vehicle by which the fusion program would move into this phase of development is designated the Engineering Test Facility (ETF). The ETF would provide a test-bed for reactor components in a fusion environment. These components would be the essential building blocks of the facilities constructed and operated during the reactor demonstration phase. These reactor demonstration phase facilities are designated the Engineering Prototype Reactor (EPR) and the Commercial Demonstration Reactor (DEMO).

In order to initiate preliminary planning for the ETF decision in the magnetic confinement approach, the Office of Fusion Energy (OFE) established the ETF Design Center activity at Oak Ridge National Laboratory (ORNL) to prepare the design of a tokamak ETF. At the same time, a Mirror ETF design task was established at Lawrence Livermore Laboratory. 
ETF design tasks will be considered for other confinement concepts as their physics performance is brought up to the level which has been achieved by the tokamak and mirror experiments. Currently the tokamak ETF effort at the ETF Design Center is receiving the highest level of support because tokamaks have achieved the highest level of plasma performance. It is noted that many of the key technological and engineering problems of magnetic confinement fusion concepts are generic in character. The emphasized effort directed toward the tokamak will be of general value to the magnetic tusion program. Such generic issues are highlighted by the needs in materials, magnets, plasma heating by beams and by radio frequency (rf) energy, impurity control and ash removal, tritium handling, maintenance, and availability/reliability.

As a point of departure for ETF activities, it was deemed essential to establish a well-defined statement on the mission of the ETF in the overall fusion program strategy. In the TNS (The Next Step) activities of FY 1978, the various design teams addressed the issue of the mission for the TNS. The Office of Fusion Energy used the mission statement results of last year's TNS activities to develop a preliminary mission statement for the ETF. In order to develop a more detailed and complete mission statement for the ETF, the ETF Design Center organized and conducted an ETF Mission Workshop held in Knoxville, Tennessee, February $13-15,1979$. The ETF Design Center used the results of the Workshop as a major input in developing the Mission Statement. The deliberations of the Workshop have been documented and can be found in ORNL/TM-6733. 
The Mission Statement presented here was prepared by the ETF Design Center, reviewed by the ETF Advisory Committee, and approved by DOE's Office of Fusion Energy. This document represents an initial effort and will be reviewed at least once a year for possible revisions. All revisions require approval by the Office of Fusion Energy.

\section{DEFINITION OF THE MISSION STATEMENT}

This Mission Statement defines the ETF activity during its operating life. The results of those operations must provide the data, knowledge, experience, and confidence to continue to the next steps beyond ETF in making fusion power a viable energy option. The results from the ETF mission (operations are assumed to start early in the 1990's) are to bridge the gap between the base of magnetic fusion knowledge at the start of operations and that required to design the EPR/DEMO devices.

The ETF mission must represent the most expeditious way to proceed to these demonstration activities even though the magnetic fusion concept choice to be ultimately used is not yet confirmed. The facility is to. address the engineering and technology issues of the march toward the fusion energy option. The understanding that most of these issues are generic to any magnetic fusion concept loosens the bounds that might otherwise restrict or delay the choice of concepts and directs the attention to the earliest fusion core that can provide the reactor environment for resolutions that will benefit almost equally the contending magnetic fusion approaches. These generic issues include materials, superconducting magnets, netural beams, rf energy injection, fucling, impurity control and helium ash removal, tritium handling, 
maintenance, plasma disruptions, and availability/reliability/operations/ cost. The emphasis on the tokamak as the first fusion core for the ETF is based on its unique advanced stage of scientific feasibility demonstration. The ETF mission will also include planned operations in support of the test and study of nongeneric or alternate-concept-specific engineering and technology issues necessary to achieve the best design foundation for proceeding with any of the probable approaches. The cost effectiveness of these design flexibilities will be carefully considered before inclusion in the ETF design.

\section{ANTICIPATED FUSION KNOWLEDGE PRIOR TO ETF OPERATION}

The start of the ETF facility operations is assumed to be in the early 1990's. In order to define the required ETF testing program or mission that will provide the achlevements needed for EPR/DEMO, the data base of physics, technology, and engineering that is expected to be available prior to the ETF operation must be assumed. These assumptions were made and were based on the guideline that only those machines now planned (plus modest upgrades) are to be considered in estimating the data base. A summary of these assumptions is included in the Appendix. A more detailed treatment is included in ORNL/TM-6733. The comparison. of this anticipated pre-ETF operation knowledge with that required to build an EPR/DEMO reveals the gaps that must be filled by advancements resulting from ETF operations. 


\section{ACHIEVEMENTS/MILESTONES}

The ETF achievements that are needed to fill the gap between the fusion understanding before ETF operations and that required for EPR/DEMO are stated below.

\section{Plasma Operations}

- Impurity and particle control

(1) Achieve reactor prototypical impurity control: low $z_{\text {eff }}$ with low $\mathrm{Z}$ impurities for long (hundreds of seconds) pulses,

(2) Demonstrate successful fueling and helium removal;

- Dynamic scenarios

(1) Optimize startup,

(2) Achieve reactor-level $\beta$ over long pulse ( $100 \mathrm{sec})$,

(3) Demonstrate stably controlled burn,

(4) Optimize the termination of high energy density plasma discharges.

Heating/Fueling Technology

- Beams - obtain high availability ( $290 \%)$ of $50 \mathrm{MW}$;

- RF - achieve high availability ( $(90 \%)$ of selected system at power levels of 10-50 MW;

- Pellets

(1) Achieve $98 \%$ availability in sustained fueling mode,

(2) Optimize pellet size, penetration, and feed rate. 
Tritium/Particle Collection Technology

- Demonstrate successful particle collection and recycling for long ( $100 \mathrm{sec})$ pulse D-T burns;

- Demonstrate the tritium handling and control capabilities necessary for EPR/DEMO designs.

\section{Blanket/First Wall/Shield Technology}

- Determine the adequacy of first wall designs for EPR/DEMO applications, withstanding physical and chemical sputtering, load cycling, neutron damage, and plasma disruptions and permitting ready replacement;

- Determine the adequacy of tritium breeding blanket designs for EPR/DEMO applications with respect to breeding ratio, cyclic thermal/hydraulic conditions, neutron damage, and replacement;

- Determine the adequacy of EPR/DEMO shield design concepts, including penetration shields, with regard to shielding effectivencss, activation, shiold cooling, repair, and replacement.

Maintenance and Engineering Operations

- Demonstrate maintainability of device components;

- Obtain experience from ETF operation for maintainability and dఆBign of EPR/DEMO.

\section{Materials}

- Determfne the perfurmance of iritical EFR/DEMO matcrials in the fusion environment (requires at least $6 \mathrm{MWyr} / \mathrm{m}^{2}$ ). 


\section{Alternate Concepts}

- Determine specific problems that can be addressed with no major ETF design impact, incorporate necessary flexibility, and accomplish tests.

\section{TESTING SCHEDULE REQUIREMENTS}

The necessary ETF achievements/milestones can be put into three categories: (1) machine dedicated - other test activities are largely interfered with, (2) noninterference - other concurrent significant test activity can continue, and (3) continuous - activities which are conducted as a part of the normal operation.

There is a recognized need for a hydrogen test period, which is also a shakedown period during which the integrated operation of the ETF is checked out in an essentially hands-on mode. In this period an ambitious test schedule for plasma operations is required, and some of the remote maintenance techniques must be proved. The highlights of the testing needs in the hydrogen test phase are shown in Table 1 . Some of the tests within a subgroup area may be done in parallel, so the individual test times do not add up to the total time shown as required for the area.

The highlights of the D-T test phase are shown in Table 2, which indicates a rather extensive set of needs. The selection and timing of these tests, shown in the operations schedule (Fig. 1), required consideration of three priorities. The guidelines used.for choosing these priorities are (1) tests on those elements that are considered most 
Table 1. Hydrogen phase test needs ( $\sim 1$ year)

\begin{tabular}{|c|c|}
\hline Test area & Test time ${ }^{a}$ \\
\hline Plasma (assuming $25 \%$ machine availability) & Dedicated time $\leqslant 1$ year \\
\hline Achieve adequate cleanliness in hydrogen & 3 months \\
\hline Optimize $I_{p}$ initiation and rampup & 2 months \\
\hline Achieve $\mathrm{nt}^{\mathrm{P}}>10^{14} \mathrm{~cm}^{-3} \mathrm{sec}$ & 7 months \\
\hline Achieve adequate heating scenario (physics) & \\
\hline Produce and control modest $\beta$ plasmas & 4 months \\
\hline $\begin{array}{l}\text { Optimize shutdown for high energy density } \\
\text { hydrogen plasmas }\end{array}$ & \\
\hline
\end{tabular}

Heating/fueling technology

Noninterference time $\leqslant 1$ year

Achieve necessary beam heating and pellet injection test experience and confidence to enter $D-T$ phase

Particle collection technology

Noninterference time $\leqslant 1$ year

Demonstrate divertor to the extent hydrogen operation will permit

Maintenance/engineering operations

Noninterference time $\leqslant 1$ year

Test maintenance techniques and procedures which cannot be done on major mockups and during machine assembly

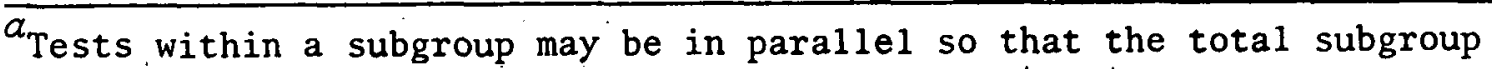
time will not equal the sum of the specific tests times.
} 
Table 2. D-T phase test needs (>15 years)

\begin{tabular}{|c|c|}
\hline Test area & Test time \\
\hline Plasma (assuming 25\% machine availability) & Dedicated time $\sim 1$ year \\
\hline Achieve $Q>5$ & \multirow{3}{*}{6 months } \\
\hline Demonstrate thermal control. & \\
\hline $\begin{array}{l}\text { Quantify alpha particle heating and } \\
\text { transport }\end{array}$ & \\
\hline $\begin{array}{l}\text { Produce and control high } \beta \text {, ignited, D-T } \\
\text { plasma for long times }\end{array}$ & \multirow{6}{*}{6 months } \\
\hline $\begin{array}{l}\text { Demonstrate reactor prototypical impurity } \\
\text { control }\end{array}$ & \\
\hline $\begin{array}{l}\text { Demonstrate fuel depletion and ash accumu- } \\
\text { lation control }\end{array}$ & \\
\hline $\begin{array}{l}\text { Establish reliable fusion core operation } \\
\text { for engineering testing }\end{array}$ & \\
\hline $\begin{array}{l}\text { Validate scaling laws in reactor-relevant } \\
\text { regime }\end{array}$ & \\
\hline Optimize fusion plasma performance & \\
\hline
\end{tabular}

Heating/fueling technology

Noninterference time $\sim 7$ years

Demonstrate efficiency and reliability for $\mathrm{EPR} / \mathrm{DEMO}$

Tritium/particle collection

Noninterference time $\sim 10$ years technology

Divertor collector tests fur $E P R / D E M O$

2,5 years

Performance and reliability necessary for $E P R / D E M O$

$\sim 2$ years

Demonstrate fuel processing and $T_{2}$ inventory control for EPR/DEMO

8 years

Blanket/first wall technology

$\sim 14$ years

Test and qualify first wall design for EPR/DEMO

ح5 years

Electricity production demonstrated

$\sim 5$ years

$\mathrm{T}_{2}$ breeding blanket design tested and qualified (two tested) for EPR/DEMO

$\sim 7$ years

Shield concepts tested and qualified for EPR/DEMO

$\sim 10$ years

Synthetic fuel blanket candidates tested and qualified

$\sim 4$ years 
Table 2 (continued)

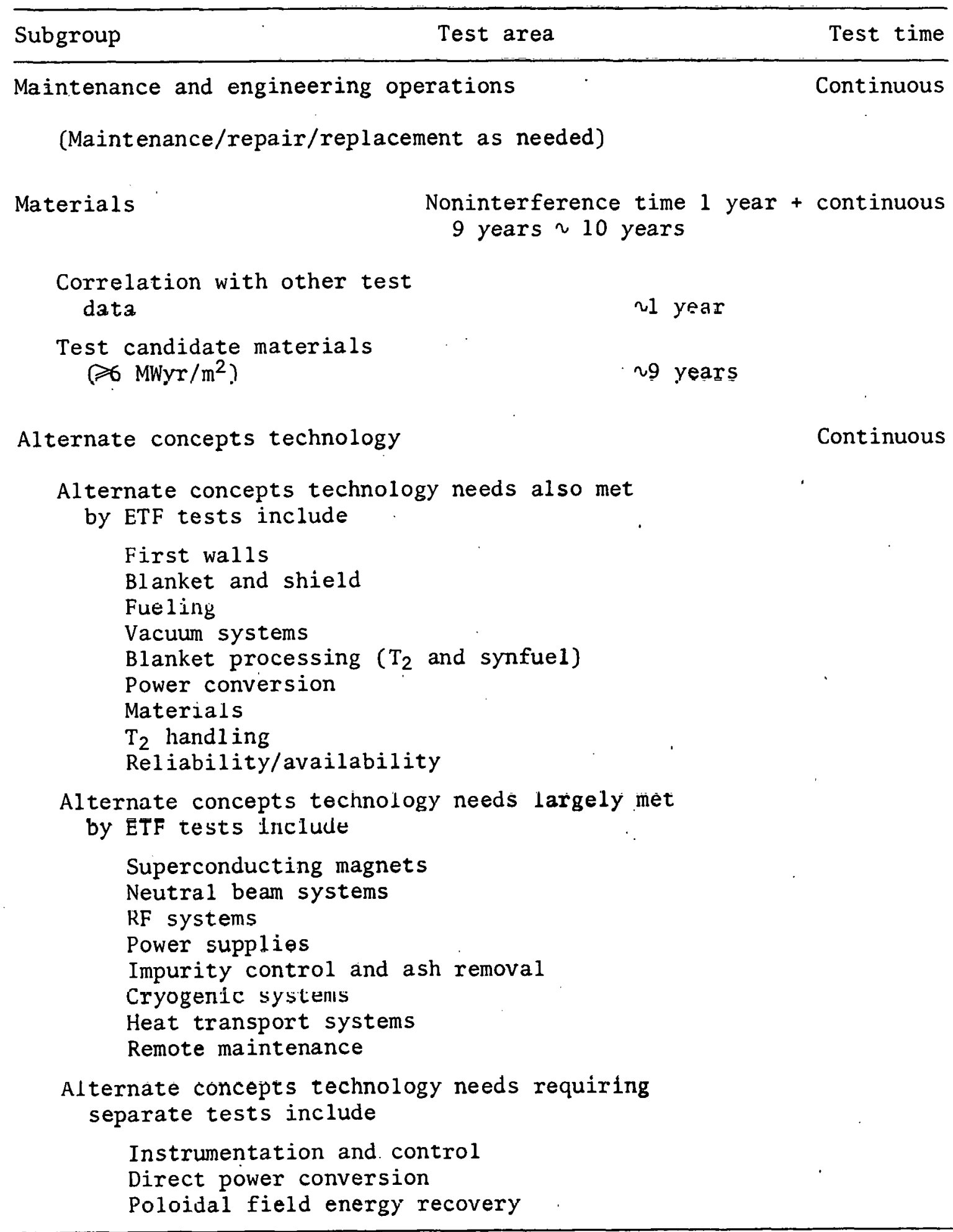


OPERATIONS SCHEDULE FOR THE ENGINEERING TEST FACILITY

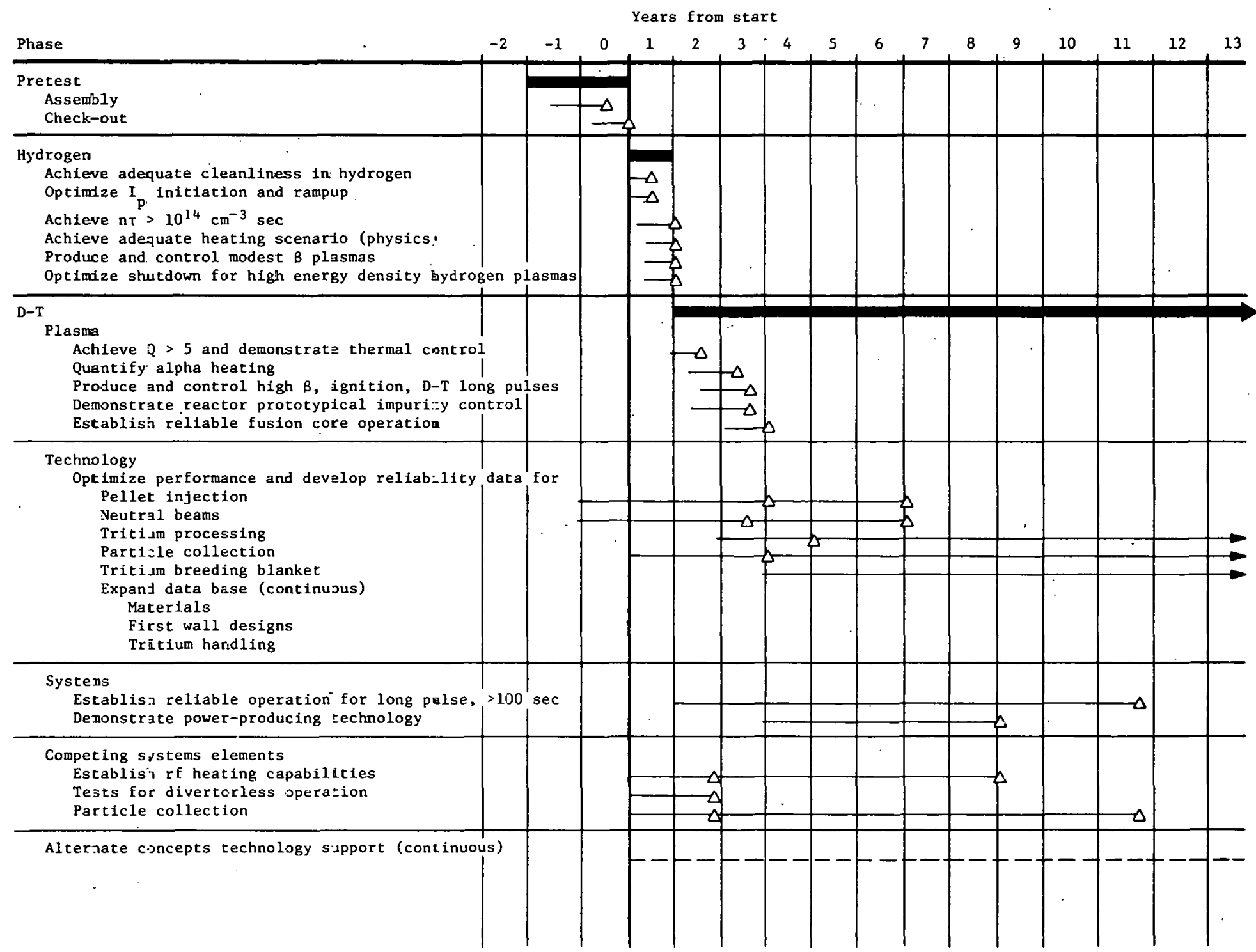

Fig. 1. Operations schedule for the Engineering Test Facility. 
likely to become the basic components of the EPR/DEMO; (2) activities that determine preferences among competing technologies, components, or approaches for EPR/DEMO; and (3) those operations that are more generic and add to the general data base for future reactor designs.

The first priority tests aim at the establishment of confidence in the reliability and availability of systems that are expected to form the foundation for the EPR/DEMO designs. A test of electricity production would be such an example. A second priority test example would be the testing of $\mathrm{rf}$ plasma heating to determine if it is a better approach than neutral beams or if a combination would be preferred. A third priority test would include the evaluation of a synthetic fuel blanket that provides data valuable for all reactor design considerations but not necessarily essential to the EPR/DEMO success.

\section{FACILITY DESCKIY'IIUN AND UESIGN REQUIREMENTS}

The results of the integration and time phasing of test priorities provide the basis for a general description of a facility with the following characteristics, which are designated the ETF Preliminary Design Requirements :

(1) The first fusion core, a tokamak, is to be an ignited, long pulse, D-T burning machine.

(2) The initial conceptual design effort should include a divertor system, and it is expected that a divertor system will be included throughout the Conceptual Design phase. Continuing parallel studies will provide guidance in comparing a bundle (in the present baseline 
design) with a poloidal divertor and divertors with divertorless operation. Although it is doubtful that experiments would support the selection of a divertorless ETF design before 1984, the appropriate design modifications to reflect this choice could be made even into the Title I Design Phase.

(3) The device design should include neutral beams as the prime plasma heating approach but provide the flexibility for $r f$ heating at equivalent power levels. Narrowing the rf candidate frequencies to one is desired. The capability for combined $\mathrm{rf}$ and neutral beam heating should be planned.

(4) The device availability (defined as the percentage of calendar time when the machine is operational for testing) shall be targeted for $25 \%$ during hydrogen operation and the first two years of D-T operation. The target availability thereafter is $50 \%$. All systems shall be designed to their necessary reliability goals to achieve this availability.

(5) Fueling will be provided by pellet injection and gas puffing.

(6) The device design will have a secondary vacuum enclosure.

(7) The ETF maintenance concept shall be reactor relevant. Design envelopes shall be established for areas in which remote, semiremote, and hands-on maintenance will be applied. Specific means for repair or replacement of all components within the remote and semiremote envelopes which are subject to failure during the expected life of the facility must be developed and demonstrated prior to ETF initial operation. Emphasis is to be placed on minimizing the size of the envelopes within which remote and semiremote maintenance will be required, consistent with the need to achieve the lowest mission cost. An ETF 
design goal shall be to allow hands-on maintenance external to the toroidal field coil shield.

(8) The means for testing different blanket, first wall, and shield modules will be incorporated. Ease of changeout of test items will be a design requirement. Reactor-relevant electricity and synfuel production modules and tritium breeding blanket modules will be tested.

(9) Material test stations will be provided in the design. Their number and size will be assessed in the Conceptual Design phase.

(10) The device is to provide a tıme-integrated wall load of $\geqslant 6 \mathrm{MWyr} / \mathrm{m}^{2}$ during its mission.

(11) Systems shakedown and check-out will be completed during assembly and prior to the beginning of scheduled operations.

(12) The feasibility and impact of providing for the testing of fusion-fission hybrid blanket modules will be assessed, and recommendations to OFE on their inclusion in the facility will be made in the Conceptual Design phase.

(13) A decomnissioning and post-mortem period will be incorporated to permit remote maintenance and disassembly and materials investigation.

(14) Testing and qualification of reactor-relevant diagnostics will be included. 
APPENDIX

ANTICIPATED FUSION KNOWLEDGE IN' 1990

(Assumes modest program increases and upgrades of present machines.)

Plasma Operations

- Impurity control

(1) Understanding of divertor physics and long pulse impurity control feasibility under high power load; demonstrations limited to short (compared to $100 \mathrm{sec}$ ) pulses;

(2) Divertorless operation will have been explored on a variety of devices.

- Dynamic scenarios

(1) Startup - quantifiable information on all aspects;

(2) Heating - demonstration of density buildup and over-dense injection heating; demonstration of rf heating feasibility;

(3) Stability control - plasma $\beta$ and its control;

(4) Burn $-Q>1$ operation information from core of 'I'FTK, JE'l' by 1990;

(5) Shutdown - understanding of. fusion quench and current rampdown and abort scenarios.

\section{Heating/Fueling Technology}

- Neutral beams

(1) Positive ion systems operational capability - $150 \mathrm{keV}$, 5-6-sec pulse, 50-MW systems, $40 \%$ efficiency with direct recovery, $2 \mathrm{~kW} / \mathrm{cm}^{2}, \mathrm{D}^{0}$;

(2) Negative ion beams development tests - 2\%50 keV. 
- RF heating status

(1) Significant testing accomplished in ECRF - T-10, ISX, EBT-P ICRF - PLT, PDX, TFTR, . . Lower hybrid - MW range Alcator C, PLT;

(2) Test results will have determined the efficacy of rf preionization and the relative capabilities of the different methods for bulk plasma heating.

- Pellet injection capabilities $-1-3 \mathrm{~mm}, 1000-3000 \mathrm{~m} / \mathrm{sec}$, 20-100 pellets/sec.

Tritium/Particle Collection Technology

- Technology for between pulse pumpdown in hand;

- Divertor requirements resolved and particle collection method demonstrated;

- TSTA will have demonstrated a workable system for fuel processing;

- Tritium supply and control methods verified;

- Security classification and accounting issues resolved.

Blanket/First Wall/Shield Technology

- Substantial data from many machines and facilities though with modest particle and heat fluxes;

- Modest technology advancements made, limited by lack of adequate nuclear test facilities;

- Complete control and/or avoidance of plasma disruptions not established, but controlled disruptions or essentially disruption-free operations can be obtained. 
Maintenance and Engineering Operations

- Heavy duty remote maintenance systems including transport pellets and servomanipulators along with the necessary viewing systems will be available;

- Mockups and models will have been built and used to support ETF design and assembly.

Materials

- The testing of materials in various facilities including ORR and FMIT will provide adequate confidence to build ETF;

- Adequate nonirradiated materials properties have been proven by test prior to ETF operation.

\section{Alternate Concepts}

- The status of concept-specific data will be in the research or development testing phase. 
THIS PAGE

WAS INTENTIONALLY

LEFT BLANK 
ORNL/TM-6732

Dist. Category UC-20 d

INTERNAL DISTRIBUTION

1. R. G. Alsmiller

2. W. R. Becraft

3. M. Bender

4. L. A. Berry

5. E. E. Bloom

6. A. L. Boch

7. T. G. Brown

8. E. H. Bryant

9. R. E. Clausing

10. R. W. Derby

11. J. H. DeVan

12. R. H. Dilworth

13. J. L. Dunlap

14. C. A. Foster

15. R. H. Fowler

16. H. H. Haselton

17. P. N. Haubenreich

18. W. A. Houlberg

19. T. J. Huxford

20. G. R. Jasny

21. R. P. Jernigan

22. T. C. Jernigan

23. R. A. Langley

24. M. S. Lube11

25. S. L. Milora

26. R. V. Miskell

27. U. B. Morgan

28. M. Murakami

29. J. G. Murray

30. R. Nygren

31. F. S. Patton
32. Y-K. M. Peng

33. H. Postma

34. R. L. Reid

35. J. A. Rome

36. M. W. Rosenthal

37. P. H. Sager

38. R. T. Santoro

39. C. Sardella

40. S. W. Schwenter1y

41. J. L. Scott

42. T. E. Shannon

43. J. Sheffield

44-68. D. Steiner

69. S. Thompson

70. N. A. Uckan

71. W. I. Van Rij

72. J. S. Watson

73. W. M. Wells

74. F. W. Wiffen

75. G. W. Wiseman

76. S. Yoshikawa

77. T. G. Yow

78-79. Laboratory Records Department

80-81. Central Research Library

82. Document Reference Section

83. Laboratory Records, ORNL-RC

84. ORNL Patont office

85-86. Fusion Energy Division Library

87. Fusion Energy Division Communications Center

\section{EXTERNAL DISTRIBUTION}

88. M. A. Abdou, School of Nuclear Engineering, Georgia Institute of Technology, Atlanta, GA 30332

89. N. A. Amherd, Fusion Power Program, Advanced Systems Department, Electric Power Research Institute, 3412 Hillview Ave., P.0. Box 10412, Palo Alto, CA 94304

90. J. L. Anderson, Los Alamos Scientific Laboratory, P.O. Box 1663, CMB-3, Ma11 Stop 348, Los Alamos, NM 87545

91. D. J. Anthony, Manager, Advanced Energy Systems, Energy Systems Programs Department, B1dg. 23, Rm. 290, General Electric Co., Schenectady, NY 12345 
92. R. E. Aronstein, Bechtel National, Inc., P.0. Box 3965, San Francisco, CA 94119

93. C. C. Baker, Fusion Power Program, Bldg. 208, Argonne National Laboratory, 9700 South Cass Ave., Argonne, IL 60439

94. R. E. Balzhiser, Director, Fossil Fuel and Advanced Systems, Electric Power Research Institute, P.0. Box 10412, Palo Alto, CA 94304

95. G. C. Banick, General Electric Co., 253 Main East, Oak Ridge, TN 37830

96. T. H. Batzer, Lawrence Livermore Laboratory, P.0. Box 808, L-536, Livermore, CA 94550

97. J. E. Baublitz, Office of Fusion Energy, ETM, Department of Energy, Mail Stop G-234, Washington, DC 20545

98. W. Bauer, Physical Research Division, Sandia LaboratoriesLivermore, Livermore, CA 94550

99. J. Beal, General Atomic Co., P.0. Box 81608, San Diego, CA 92138

100. D. S. Beard, Office of Fusion Energy, EIM, Department of Energy, Mail Stop G-234, Washington, DC 20545

101. R. J. Beeley, ETEC, Rockwell International, P.0. Box 1449, Canoga Park, CA 91304

102. G. W. Benedict, U.S. Department of Energy, Oak Ridge Operations, P.O. Box E, Oak Ridge, TN 37830

103. F. Bennett, Princeton Plasma Physics Laboratory, Princeton University, P.0. Box 451, Princeton, NJ 08540

104. D. C. Berkey, Vice President and General Manager, Energy System and Technology Division, General Electric Co., P.0. Box 7600, Stamford, CT 06904

105. E. S. Bettis, Science Applications, Inc., 800 Oak Ridge Turnpike, Oak Ridge, TN 37830

106. R. F. Beuligmann, Program Director, Energy Systems, General Dynamics, Convair Division, P.0. Box 80847, Mail Zone 12-1070, San Diego, CA 92138

107. S. L. Bogart, Science Applications, Inc., 8400 Westpark Drive, McLean, VA 22102

108. R. Botwin, C47-05, Grumman Äerospace Corp., Bethpage, NY 11714

109. N. Bowen, Princeton Plasma Physics Laboratory, Princeton University, P.0. Box 451, Princeton, NJ 08540

110. W. B. Briggs, McDonnell-Douglas Astronautics Co., P.0. Box 516, St. Louis, MO 63166

111. G. Bronner, Princeton Plasma Physics Laboratory, Princeton University, P.0. Box 451, Princeton, NJ 08540

112. S. C. Burnetr, General Atumlc Co., P.0. Box 81608, San Dlego, CA 92138

113. C. S. Caldwe11, Babcock and Wilcox, Lynchburg Research Center, P.0. Box 1260 , Lynchburg, VA 24505

114. J. D. Callen, Department of Nuclear Engineering, University of Wisconsin, Madison, WI 53706

115. A. T. Christensen, General Electric Co., Center for Energy Systems, 777 Fourteenth St., Washington, DC 20006

116. J. F. Clarke, Deputy Director, Office of Fusion Energy, ETM, Department of Energy, Mail Stop G-234, Washington, DC 20545 
117. R. G. Clemmer, Fusion Power Program, Argonne National Laboratory, 9700 South Cass Ave., Argonne, IL 60439

118. F. E. Coffman, office of Fusion Energy, ETM, Department of Energy, Mail Stop G-234, Washington, DC 20545

119. D. R. Cohn, MIT Plasma Fusion Center, NW 16-206, 167 Albany Street, Cambridge, MA 02139

120. R. W. Conn, Department of Nuclear Engineering, University of Wisconsin, Engineering Research Building, Madison, WI 53706

121. J. W. Coursen, C36-05, Grumman Aerospace Corp., Bethpage, NY 11714

122. J. G. Crocker, EG\&G Idaho, Inc., P.0. Box 1625, Idaho Falls, ID 83401

123. C. C. Damm, Lawrence Livermore Laboratory, P.0. Box 808, L-441, Livermore, CA 94550

124. R. A. Dand1, 1122 Calle de los Serranos, San Marcos, CA 92069

125. M. H. Dandridge, Grumman Aerospace Corp., Power Plant and Environment, B-14-35, Bethpage, NY 11714

126. R. Daniels, Princeton Plasma Physics Laboratory, Princeton University, P.0. Box 451, Princeton, NJ 08540

127. R. C. Davidson, MIT Plasma Fusion Center, 77 Massachusetts Ave., Cambridge, MA 02139

128. N. A. Davies, Office of Fusion Energy, ETM, Department of Energy, Mail Stop G-234, Washington, DC 20545

129. J. W. Davis, Mc.Donne11-Douglas Astronautics Co., East E457, Bldg. 81/1/C7, P.0. Box 516, St. Louis, MO 63166

130. M. J. Davis, Sandia Laboratories-Livermore, Dept. 5830, Livermore, CA. 94550

131. S. 0. Dean, Director, Fusion Energy Development, Science Applications, Inc., 2 Professional Drive, Suite 249, Gaithersburg, MD 20760

132. J. F. Decker, Office of Fusion Energy, ETM, Department of Energy, Mail Stop G-234, Washington, DC 20545

133. D. DeFreece, McDonne11-Douglas Astronautics Co., Dept. E451, B.1.dg. 81/1//C7, P.n. Box 51.6, St. Louis, MO 63166

134. A. Deitz, Princeton Plasma Physics Laboratory, Princeton University, P.0. Box 451, Princeton, NJ 08540

135. D. A. Dingee, Program Manager, Pacific Northwest Laboratories, Fusion Technology, Battelle Blvd., Richland, WA 99352

136. J. N. Doggett, Lawrence Livermore Laboratory, P.0. Box 808, L-441, Livermore, CA 94550

137. H. Dreicer, Division Leader, Los Alamos Scientific Laboratory, CRT, P.0. Box 1663, Los Alamos, NM 87545

138. R. J. Dugal, Energy Systems-Power Division, Ralph M. Parsons Co., 100 West Walnut St., Pasadena, CA 91124

139. W. R. E11is, Office of Fusion Energy, ETM, Department of Energy, Mail Stop G-234, Washington, DC 20545

140. G. A. Emmert, Department of Nuclear Engineering, University of Wisconsin, Madison, WI 53706

141. B. Engholm, General Atomic Co., P.0, Box 81608, San Diego, CA 92138

142. H. P. Eubank, Princeton Plasma Physics Laboratory, Princeton University, P.0. Box 451, Princeton, N.T 08540 
143. E. Evans, Vice President, Westinghouse-Hanford, P.0. Box 1970, Richland, WA 99352

144. B. J. Fedor, EBASCO Services, Inc., Princeton Plasma Physics Laboratory, Princeton University, P.O. Box 451, Princeton, NJ 08540

145. J. J. Ferrante, Manager, Large Superconducting Program, Bldg. 36-241, General Electric Co., 1 River Rd., Schenectady, NY 12345

146. D. Field, General Atomic Co., P.O. Box 81608, San Diego, CA 92138

147. J. File, Princeton Plasma Physics Laboratory, Princeton University, P.0. Box 451, Princeton, NJ 08540

148. C. A. Flanagan, Fusion Power Systems Department, Westinghouse Electric Corp., P.0. Box 10864, Pittsburgh, PA 15236

149. H. K. Forsen, Exxon Nuclear Co., Inc., 777 106th Ave., NE, Bellevue, WA 98004

150. J. Foster, Jr., TRW, Inc., 1 Space Park, BIdg. R4-2004, Redondo Beach, CA 90278

151. T. K. Fowler, Associate Director for MFE, Lawrence Livermore Laboratory, P.0. Box 808, L-436, Livermore, CA 94550

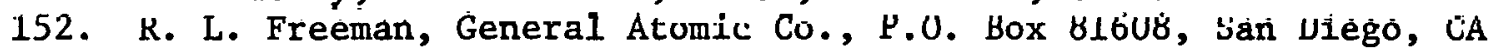
92138

153. J. W. French, EBASCO Services, Inc., Princeton Plasma Physics Laboratory, Princeton University, Forrestal Campus, CN-59, Princeton, NJ 08540

154. G. Fuller, McDonnell-Douglas Astronautics Co., Dept. E450, B1dg. 81/130, P.0. Box 516, St. Louis, MO 63166

155. H. P. Furth, Princeton Plasma. Physics Laboratory, Princeton University, P.0. Box 451, Princeton, NJ 08540

156. E. P. Gagnon, Un1ted Technologies Research Center, Silver Lane, Mall 3Lǘ 44, Last llartford, CT 06108

157. J. G. Gavin, Jr., President, Grumman Aerospace Corp., A01-111, Bethpage, NY 11714

158. J. Gilleland, Manager, Fusion Projects, General Atomic Co., P.0. Box 81608, San Diego, CA 92138

159. R. E. Gold, Westinghouse Electric Corp., f'usion Power Systems Department, P.0. Box 10864, Pittsburgh, PA 15236

160. S. Goldfarb, Princeton Plasma Physics Laboratory, Princeton University, P.0. Box 451, Princeton, NJ 08540

161. M. B. Gottlieb, Director, Princeton Plasma Physics Laboratory, Princeton University, P.0. Box 451, Princeton, NJ 08540

162. R. W. Gould, Bldg. 116-81, California Institute of Technology, Pasadena, CA 91109

163. D. W. Graumann, General Atomic Co., P.0. Box 81608, San Diego, CA 92138

164. G. E. Guest, Plasma Theory Department, General Atomic Co., Y.u. Box 81608, San Diego, CA 92138

165. E. R. Hager, General Atomic Co., P.0. Box 81608, Mail Stop L-549, San Diego, CA 92138

166. S. D. Harkness, Fusion Power Program, Bldg. 208, Argonne National Laboratory, 9700 South Cass Ave., Argonne, IL 60439

167. R. J. Hawryluk, Princeton Plasma Physics Laboratory, Princeton University, P.0. Box 451, Princeton, NJ 08540 
168. C. R. Head, Office of Fusion Energy, ETM, Department of Energy, Mail Stop G-234, Washington, DC 20545

169. H. K. Hebeler, President, Boeing Engineering and Construction Co., P.O. Box 3707, Seattle, WA 98124

170. R. L. Hirsch, General Manager for Exploratory Research, Exxon Research and Engineering Co., Box 101, Florham Park, NJ 07932

171. N. J. Hoffman, ETEC, P.O. Box 1449, T 486, Canoga Park, CA 91304

172. J. J. Holmes, Westinghouse-Hanford Engineering Development Laboratory, P.0. Box 1970, Richland, WA 99352

173. G. Homeyer, General Atomic Co., P.0. Box 81608, San Diego, CA 92138

174. W. M. Hooke, Princeton Plasma Physics Laboratory, Princeton University, P.0. Box 451, Princeton, NJ 08540

175. J. C. Hosea, Princeton Plasma Physics Laboratory, Princeton University, P.0. Box 451, Princeton, NJ 08540

176. R. Huse, Manager, Research and Development Department, PSE\&G Research Corp., 80 Park Place, Newark, NJ 07101

177. D. L. Jassby, Princeton Plasma Physics Laboratory, Princeton University, P.0. Box 451, Princeton, NJ 08540

178. B. K. Jensen, PSE\&G Research Corp., 80 Park Place, Rm. 1116, Newark, NJ 07101

179. N. E. Johnson, Science Applications, Inc., 800 Oak Ridge Turnpike, Oak Ridge, TN 37830

180. J. B. Joyce, Princeton Plasma Physics Laboratory, Princeton University, P.0. Box 451, Princeton, NJ 08540

181. E. E. Kintner, Director, Office of Fusion Energy, ETM, Department of Energy, Mail Stop G-234, Washington, DC 20545

182. R. A. Krakowski, Los Alamos Scientific Laboratory, P.0. Box 1663, CTR-12, Mail Stop 641, Los Alamos, NM 87545

183. N. A. Kral1, JAYCOR, 1401 Camino Del Mar, Del Mar, CA 92014

184. G. L. Kulcinski, University of Wisconsin, Department of Nuclear Engineering, Engineering Research Bldg., Rm. 439, 1500 Johnson Drive, Madison, WI 53706

185. D. L. Kummer, McDonne11-Douglas Astronautics Co., Dept. E457, B1dg. 81/132, P.0. Box 516, St. Louis, MO 63166

186. J. Landis, Senior Vice President, Stone and Webster Engineering Corp., 245 Summer St., Boston, MA 02107

187. T. S. Latham, United Technologies Research Center, Silver Lane, Mail Stop 44, East Hartford, CT 06108

188. J. Lawson, Princeton Plasma Physics Laboratory, Princeton University, P.0. Box 451, Princeton, NJ 08540

189. L. M. Lidsky, MIT Plasma Fusion Center, Cambridge, MA 02139

190. E. F. Lowe11, General Manager, Energy Systems Programs Department, Bldg. 2-455, General Electric Co., 1 River Rd., Schenectady, NY 12345

191. D. G. McAlees, Manager, Program Development, Laser Enrichment Department, Exxon Nuclear Co., Inc., 777 106th Ave., NE, Rellevue, WA 98004

192. D. J. McFarlin, United Technologies Research Center, Silver Lane, Mail Stop 44, East Hartford, CT 06108

193. V. A. Maroni, Argonne National Laboratory, CEN/205, 9700 South Cass Ave., Argonne, IL 60439 
194. W. Marton, Office of Fusion Energy, ETM, Department of Energy, Mail Stop G-234, Washington, DC 20545

195. L. Masson, EG\&G Idaho, Idaho National Engineering Laboratory, P.O. Box 1625, Idaho Falls, ID 83401

196. D. M. Meade, Princeton Plasma Physics Laboratory, Princeton University, P.0. Box 451, Princeton, NJ 08540

197. A. T. Mense, Subcommittee on Energy Research and Production, B-374, Rayburn House Office Bldg., Washington, DC 20515

198. L. Michaels, Princeton Plasma Physics Laboratory, Princeton University, P.0. Box 451, Princeton, NJ 08540

199. R. Micich, Grumman Aerospace Corp., Bethpage, NY 11714

200. R. L. Miller, General Atomic Co., P.0. Box 81608, San Diego, CA 92138

201. R. G. Mills, Princeton Plasma Physics Laboratory, Princeton University, P.0. Box 451, Princeton, NJ 08540

202. J. T. D. Mitche11, Culham Laboratory, Abingdon, Oxon, OX14 3DB, United Kingdom

203. P. B. Mohr, Lawrence Livermore Laboratory, P.0. Box 808, Livermore, CA 94550

204. R. W. Moir, Lawrence Livermore Laboratory, P.0. Box 808, Livermore, CA 94550

205. D. B. Montgomery, MIT Plasma Fusion Center, 170 Albany St., Cambridge, MA 02139

206. K. Moses, TRW, Inc., R-1/1078, 1 Space Park, Redondo Beach, CA 90278

207. R. E. Mullen, Aerojet Manufacturing Co., 601 South Placentia Ave., P.0. Box 4210, Fullerton, CA 92934

208. A. E. Munier, Grumman Aerospace Corp., Bethpage, NY 11714

209. M. R. Murphy, of fice of Fusion Energy, ETM, Department of Energy, Mail Stop G-234, Washington, DC 20545

210. V. S. O'Block, Westinghouse Electric Corp. (CRBRP), P.0. Box W, Oak Ridge, TN 37830

211. T. Ohkawa, Vice President, General Atomic Co., P.0. Box 81608, San Diego, CA 92138

212. M. Okabayashi, Princeton P̄lasma Physics Laboratory, Princeton University, P.0. Box 451, Princeton, NJ 08540

213. R. R. Parker, MIT, NW14-2506, National Magnet Laboratory, 170 Albany St., Cambridge, MA 02139

214. P. B. Parks, General Atomic Co., P.0. Box 81608, San Diego, CA 92138

215. B. Pease, Culham Laboratory, Abingdon, Oxon, OX14 3DB, United Kingdom

216. M. Porkolab, Massachusetts Institute of Technology, Cambridge, MA 02139

217. L. K. Price, U.S. Department of Energy, Oak Ridge Operations, P.0. Box E, Oak Ridge, TN 37830

218. R. E. Price, Office of Fusion Energy, ETM, Department of Energy, Mail Slup G=234, Washinglun, DC 20545

219. D. H. Priester, Office of Fusion Energy, ETM, Department of Energy, Mail Stop G-234, Washington, DC 20545

220. F. A. Puhn, General Atomic Co., P.0. Box 81608, San Diego, CA 92138 
221. R. V. Pyle, University of California, Lawrence Berkeley Laboratory, Berkeley, CA 94720

222. J. M. Rawls, General Atomic Co., P.0. Box 81608, San Diego, CA 92138

223. P. J. Reardon, Princeton Plasma Physics Laboratory, Princeton University, P.0. Box 451, Princeton, NJ 08540

224. E. E. Reis, General Atomic Co., P.0. Box 81608, San Diego, CA 92138

225. D. R. Riley, CRBRP Project Office, P.O. Box U, Oak Ridge, TN 37830

226. M. Roberts, Office of Fusion Energy, ETM, Department of Energy, Mail Stop G-234, Washington, DC 20545

227. J. D. Rogers, Los Alamos Scientific Laboratory, P.0. Box 1663, Los Alamos, NM 87545

228. S. N. Rosenwasser, General Atomic Co., P.0. Box 81608, 15/219, San Diego, CA 92138

229. P. Rutherford, Princeton Plasma Physics Laboratory, Princeton University, P.0. Box 451, Princeton, NJ 08540

230. J. Scharer, Department of Nuclear Engineering, University of Wisconsin, Engineering Research Bldg., Madison, WI 53706

231. J. A. Schmidt, Princeton Plasma Physics Laboratory, Princeton University, P.0. Box 451, Princeton, NJ 08540

232. J. Schultz, Massachusetts Institute of Technology, 167 Albany St., Cambridge, MA 02139

233. F. R. Scott, Electric Power Research Institute (EPRI) Fusion Program, 3412 Hillview Ave., P.o. Box 10412, Palo Alto, CA 94304

234. F. Seibel, Princeton Plasma Physics Laboratory, Princeton University, P.0. Box 451, Princeton, NJ 08540

235. Z. M. Shapiro, Manager, Fusion Power Systems, Westinghouse Electric Corp., P.0. Box 10864, Pittsburgh, PA 15236

236. G. Sheffield, Princeton Plasma Physics Laboratory, Princeton University, P.0. Box 451, Princeton, NJ

237. T. J. M. Sluyters, Brookhaven National Laboratory, Accelerator Department, Upton, Long Island, NY 11973

238. D. Smith, Materials Science Division, Argonne National Laboratory, 9700 South Cass Ave., Argonne, IL 60439

239. R. I. Smith, Board Chairman, Public Service Electric and Gas Co., 80 Park Place, Newark, NJ 07101

240. M. Sniderman, Westinghouse, Fusion Project, 1823 Wightman St., Pittsburgh, PA 15217

241. L. Southworth, General Atomic Co., P.0. Box 81608, San Diego, CA 92138

242. P. T. Spampinato, Grumman Aerospace Corp., Bethpage, NY 11714

243. W. M. Stacey, Jr., Georgia Institute of Technology, School of Nuclear Engineering, Atlanta, GA 30332

244. M. Stauber, Grumman Aerospace Corp., Bethpage, NY 11714

245. L. D. Stewart, Princeton Plasma Physics Laboratory, Princeton University, P.0. Box 451, Princeton, NJ 08540

246. P. M. Stone, Office of Fusion Energy, ETM, Department of Energy, Mail Stop G-234, Washington, DC 20545

247. J. L. Straalsund, Westinghouse-Hanford, P.0. Box 1970, Richland, WA 99352

248. I. N. Sviatoslavsky, University of Wisconsin, 1500 Johnson Drive, R̂m. 333 ERB, Madisun, WI 53706 
249. T. Tamano, General Atomic Co., P.0. Box 81608, San Diego, CA 92138

250. C. E. Taylor, Lawrence Livermore Laboratory, P.0. Box 808, Livermore, CA 94550

251. F. Tenney, Princeton Plasma Physics Laboratory, Princeton University, P.0. Box 451, Princeton, NJ 08540

252. F. Thomas, Grumman Aerospace Corp., B-20-5, Bethpage, NY 11714

253. K. I. Thomassen, Lawrence Livermore Laboratory, P.0. Box 808, Livermore, CA 94550

254. R. J. Thome, Massachusetts Institute of Technology, Bldg. NW-16-229, I70 Albany St., Cambridge, MA 02139

255. C. Trachse1, McDonne11-Douglas Astronautics Co., P.0. Box 516, St. Louis, MO 63166

256. J. R. Treglio, General Dynamics, Convair Division, P.0. Box 80847, San Diego, CA 92138

257. A. W. Trivelpiece, Science Applications, Inc., 1200 Prospect St., P.O. Box 2351, La Jolla, CA 92038

258. T. C. Varljen, Westinghouse Electric Corp., P.0. Box 10864, Pittsburgh, PA 15236

259. S. S. Wadde11, U.S. Department of Energy, Oak Ridge Operations, P.O. Box E, Oak Ridge, TN 37830

260. A. Wait, Project Engineer, Advanced Applications, Bldg. 36-421, General Electric Co., 1 River Rd., Schenectady, NY 12345

261. K. E. Wakefield, Princeton Plasma Physics Laboratory, Princeton University, P.O. Box 451, Princeton, NJ 08540

262. D. Weldon, Los Alamos Scientific Laboratory, P.0. Box 1663, Mail Stop 464, Los Alamos, NM 87545

263. F. G. Welfare, Babcok and Wilcox, Lynchburg Research Center, P.0. Box 1260, Lynchburg, VA 24505

264. 'R. W. Werner, Lawrence Livermore Laboratory, P.0. Box 808, Livermore, CA 94550

265. W. R. Wilkes, Monsanto Research Corp., Mound Laboratory, Miamisburg, $\mathrm{OH}$ ' 45342

266. J. E. Wilkins, EG\&G Idaho, Idaho National Engineering Laboratory, Idaho Falls, ID 83401

267. H. Willenberg, Mathematical Sciences, Northwest, P.0. Box 1887, Bellevue, WA 98009

268. J. E. C. Williams, B1dg. NW16-3210, Massachusetts Institute of Technology, 170 Albany St., Cambridge, MA 02139

269. J. M. Williams, Los Alamos Scientific Laboratory, P.O. Box 1663, Los Alamos, NM 87545

270. P. Willis, General Electric Co., 1 River Rd., Bldg. 23, Rm. 298, Schenectady, NY 12345

271. K. E. Wright, Princeton Plasma Physics Laboratory, Princeton University, P.O. Box 451, Princeton, NJ 08540

272. T. F. Yang, Westinghouse Electric Corp., Fusion Power Systems Department, P.O. Box 10864, Pittsburgh, PA 15236

273. H. H. Yoshikawa, Hanford Engineering Development Laboratory W/A-62, P.0. Box 1970, Richland, WA 99352

274. N. E. Young, EBASCO Services, Inc., Princeton Plasma Physics Laboratory, Princeton University, P.0. Box 451, Princeton, NJ 08540 
275. K. M. Zwilsky, Office of Fusion Energy, ETM, Department of Energy, Mail Stop G-234, Washington, DC 20545

276. Office of Assistant Manager, Energy Research and Development, Department of Energy, Oak Ridge Operations Office, Oak Ridge; TN 37830

277-413. Given distribution as shown in TID-4500, Magnetic Fusion Energy (Distribution Category UC-20 d, Fusion Systems) 